\title{
Transmission of severe acute respiratory syndrome coronavirus 2 (SARS-CoV-2) to animals: an updated review
}

Sina Salajegheh Tazerji ${ }^{13^{*}} \mathbb{0}$, Phelipe Magalhães Duarte ${ }^{2}$, Parastoo Rahimi ${ }^{3}$, Fatemeh Shahabinejad ${ }^{4}$, Santosh Dhakal ${ }^{5}$, Yashpal Singh Malik ${ }^{6}$, Awad A. Shehata ${ }^{7,8}$, Juan Lama ${ }^{9}$, Jörn Klein ${ }^{10}$, Muhammad Safdar ${ }^{11}$, Md. Tanvir Rahman ${ }^{12}$, Krzysztof J. Filipiak ${ }^{13}$, Alfonso J. Rodríguez-Morales ${ }^{14}$, Md. Abdus Sobur ${ }^{12}$, Farrokhreza Kabir ${ }^{15}$, Bita Vazir ${ }^{16}$, Leonard Mboera ${ }^{17}$, Marco Caporale ${ }^{18}$, Md. Saiful Islam ${ }^{12}$, John H. Amuasi ${ }^{19}$, Rasha Gharieb ${ }^{20}$, Paola Roncada ${ }^{21}$, Sahar Musaad ${ }^{22}$, Bruno Tilocca ${ }^{21}$, Mohammad Kazem Koohi ${ }^{23}$, Ali Taghipour ${ }^{24}$, Ahmet Sait ${ }^{25}$, Kannan Subbaram ${ }^{26}$, Alireza Jahandideh ${ }^{15}$, Pejman Mortazavi ${ }^{27}$, Mohammad Amin Abedini ${ }^{3}$, David A. Hokey ${ }^{28}$, Unarose Hogan ${ }^{29}$, Mohamed N. F. Shaheen ${ }^{30}$, Ahmed Elaswad ${ }^{31}$, Mahmoud M. Elhaig ${ }^{32}$ and Mohamed Fawzy ${ }^{33}$

\begin{abstract}
COVID-19 caused by a novel severe acute respiratory syndrome coronavirus 2 (SARS-CoV-2) originated in Wuhan (Hubei province, China) during late 2019. It has spread across the globe affecting nearly 21 million people with a toll of 0.75 million deaths and restricting the movement of most of the world population during the past 6 months. COVID-19 became the leading health, economic, and humanitarian challenge of the twenty-first century. In addition to the considerable COVID-19 cases, hospitalizations, and deaths in humans, several cases of SARS-CoV-2 infections in animal hosts (dog, cat, tiger, lion, and mink) have been reported. Thus, the concern of pet owners is increasing. Moreover, the dynamics of the disease requires further explanation, mainly concerning the transmission of the virus from humans to animals and vice versa. Therefore, this study aimed to gather information about the reported cases of COVID-19 transmission in animals through a literary review of works published in scientific journals and perform genomic and phylogenetic analyses of SARS-CoV-2 isolated from animal hosts. Although many instances of transmission of the SARS-CoV-2 have been reported, caution and further studies are necessary to avoid the occurrence of maltreatment in animals, and to achieve a better understanding of the dynamics of the disease in the environment, humans, and animals. Future research in the animal-human interface can help formulate and implement preventive measures to combat the further transmission of COVID-19.
\end{abstract}

Keywords: Coronavirus, COVID-19, SARS-CoV-2, Pandemic, Zoonoses, Pet animals, Animals, Epidemiology, One Health

*Correspondence: sina.salajegheh@gmail.com

${ }^{3}$ Faculty of Veterinary Medicine, Science and Research Branch, Islamic Azad University, Tehran, Iran

Full list of author information is available at the end of the article

\section{Introduction}

The outbreak of Coronavirus disease-2019 (COVID-19) leading to pneumonia of unknown origin was linked to the Huanan Seafood Wholesale Market located in the city of Wuhan, Hubei province, China [1,2]. The pathogen was soon identified as a novel coronavirus named as

(c) The Author(s) 2020. This article is licensed under a Creative Commons Attribution 4.0 International License, which permits use, sharing, adaptation, distribution and reproduction in any medium or format, as long as you give appropriate credit to the original author(s) and the source, provide a link to the Creative Commons licence, and indicate if changes were made. The images or other third party material in this article are included in the article's Creative Commons licence, unless indicated otherwise in a credit line to the material. If material is not included in the article's Creative Commons licence and your intended use is not permitted by statutory regulation or exceeds the permitted use, you will need to obtain permission directly from the copyright holder. To view a copy of this licence, visit http://creativeco mmons.org/licenses/by/4.0/. The Creative Commons Public Domain Dedication waiver (http://creativecommons.org/publicdomain/ zero/1.0/) applies to the data made available in this article, unless otherwise stated in a credit line to the data. 
severe acute respiratory syndrome coronavirus 2 (SARS$\mathrm{CoV}-2$ ) and the disease was referred to as Coronavirus disease-2019 (COVID-19) [3]. The SARS-CoV-2 is the third coronavirus that has emerged in the last two decades. Others are the severe acute respiratory syndrome coronavirus (SARS-CoV) and the Middle East respiratory syndrome coronavirus (MERS-CoV), which emerged during 2002 and 2012, respectively [2, 4]. Compared to SARS-CoV and MERS-CoV, SARS-CoV-2 is responsible for the most significant economic loss and the highest number of infections and deaths [5]. Until 13 August 2020 around 21 million COVID-19 cases and over 0.75 million deaths have been reported. SARS-CoV-2 belongs to the order Nidovirales, suborder Coronavirineae, and family Coronaviridae. The family Coronaviridae contains two subfamilies named Lentovirinae and Orthocoronavirinae. The latter is further classified into four genera, namely Alphacoronavirus ( $\alpha \mathrm{CoV})$, Betacoronavirus $(\beta \mathrm{CoV})$, Gammacoronavirus $(\gamma \mathrm{CoV})$, and Deltacoronavirus $(\delta \mathrm{CoV})$, as shown in Fig. 1 . The $\gamma \mathrm{CoVs}$ and $\delta \mathrm{CoVs}$ cause diseases in birds while $\alpha \mathrm{CoVs}$ and $\beta \mathrm{CoVs}$ are mainly found in mammals such as bats, rodents, civets, pigs, horses, cattle and humans [6-9]. SARS-CoV-2 clusters with lineage $\beta \mathrm{CoV}$ together with SARS-CoV and MERS-CoV [8]; both originating from bats $[1,10,11]$.

Coronaviruses are enveloped viruses with singlestranded positive-sense RNA $(+s s)$ and genome size between 26 and $32 \mathrm{~kb}$ in length [12, 13]. These viruses possess four essential structural proteins: spike glycoprotein $(S)$, matrix protein $(M)$, envelope protein $(E)$, and nucleocapsid protein $(\mathrm{N})[13-15,22]$. According to the genomic analysis, SARS-CoV-2 shares a $96.2 \%$ identity with the genome of bat CoV; RaTG13, indicating a possible origin of the virus in bats $[3,16]$. Several studies suggested that the pangolin could be the potential intermediate host involved in the evolution of the virus because of the unique receptor-binding domain configuration [17-19, 22].

Among the global fear due to the rapid spread of the COVID-19 and absence of specific treatment or vaccine,

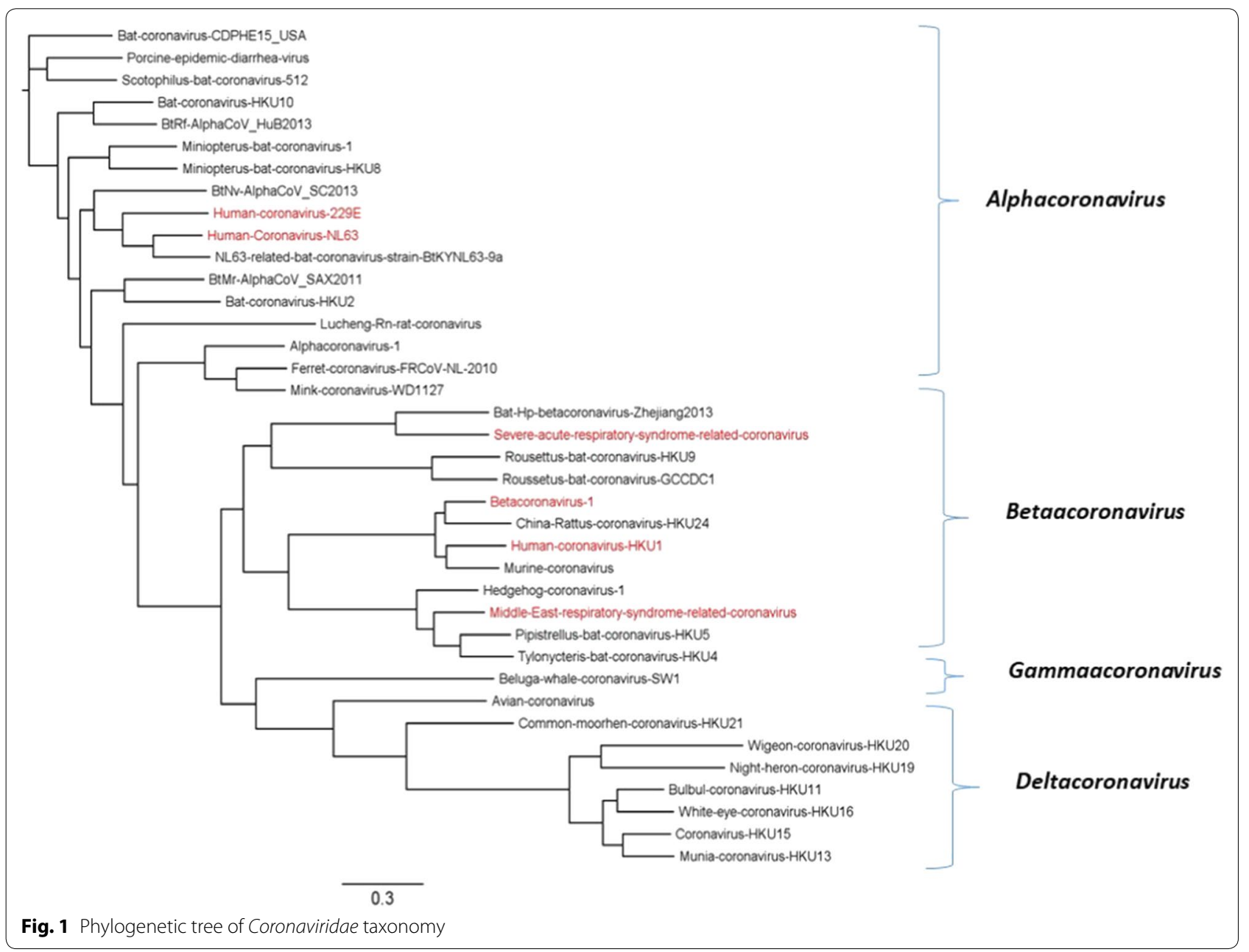


the first case of human-to-animal transmission was recorded in Hong Kong, where a 17-years-old Pomeranian dog was affected [20]. This case raised concerns about the possibility of SARS-CoV-2 transmission from humans to animals and vice versa, which would represent the difficulties in fighting the virus significantly. However, based on recently published findings, other authors hypothesized that an immunological cross-protection between SARS-CoV-2 and canine respiratory coronavirus $(\mathrm{CRCoV})$ exists due to the high homology between the spike protein epitopes of the two taxonomicallyrelated coronaviruses [21].

The objective of the present study was to gather, present, and discuss information on the reported cases of COVID-19 in animals focusing on the virus transmission cases in pets and perform genomic and phylogenetic analyses of SARS-CoV-2 isolated from animal hosts. Further studies on the dynamics of the disease are essential to adopt suitable control measures to reduce transmission of the virus.

\section{Possible origin of the new coronavirus}

To discuss the origin of SARS-CoV-2, it is necessary to analyze the source of other coronaviruses such as SARS$\mathrm{CoV}$ and MERS-CoV, as shown in Fig. 2 [22]. SARS-CoV emerged in Guangdong province, Southern China, in November 2002 and was characterized as a contagious respiratory disease of humans [22, 23]. Records showed 8422 registered cases and 916 deaths in humans, spreading to 29 countries during the epidemic with a case fatality rate (CFR) of 9.6\% [23]. Studies revealed the presence of several coronaviruses in species of horseshoe bats (genus Rhinolophus), which are evolutionarily related to SARS-CoV in their genome organization and sequence $[24,25]$. In the further investigations of the initial SARS outbreak of 2002 in Hong Kong, it was recognized that cats (Felis domesticus) and ferrets (Mustela furo) could be infected with SARS-CoV [26].

In 2012, another coronavirus causing severe acute respiratory syndrome in humans was first reported in Saudi Arabia and was later called the Middle East respiratory syndrome coronavirus (MERS-CoV) [27]. MERS-CoV is $\beta \mathrm{CoV}$ of the $\mathrm{C}$ lineage with a genotype very similar to that of bats of the same line, such as BtCoV-HKU4 and BtCoVHKU5 [28].

The transmission of MERS-CoV to dromedaries was identified through the detection of specific antibodies against the virus in these animals [29]. According to Corman et al. [30], MERS-CoV has been circulating in dromedaries for more than 20 years [30]. Therefore, it

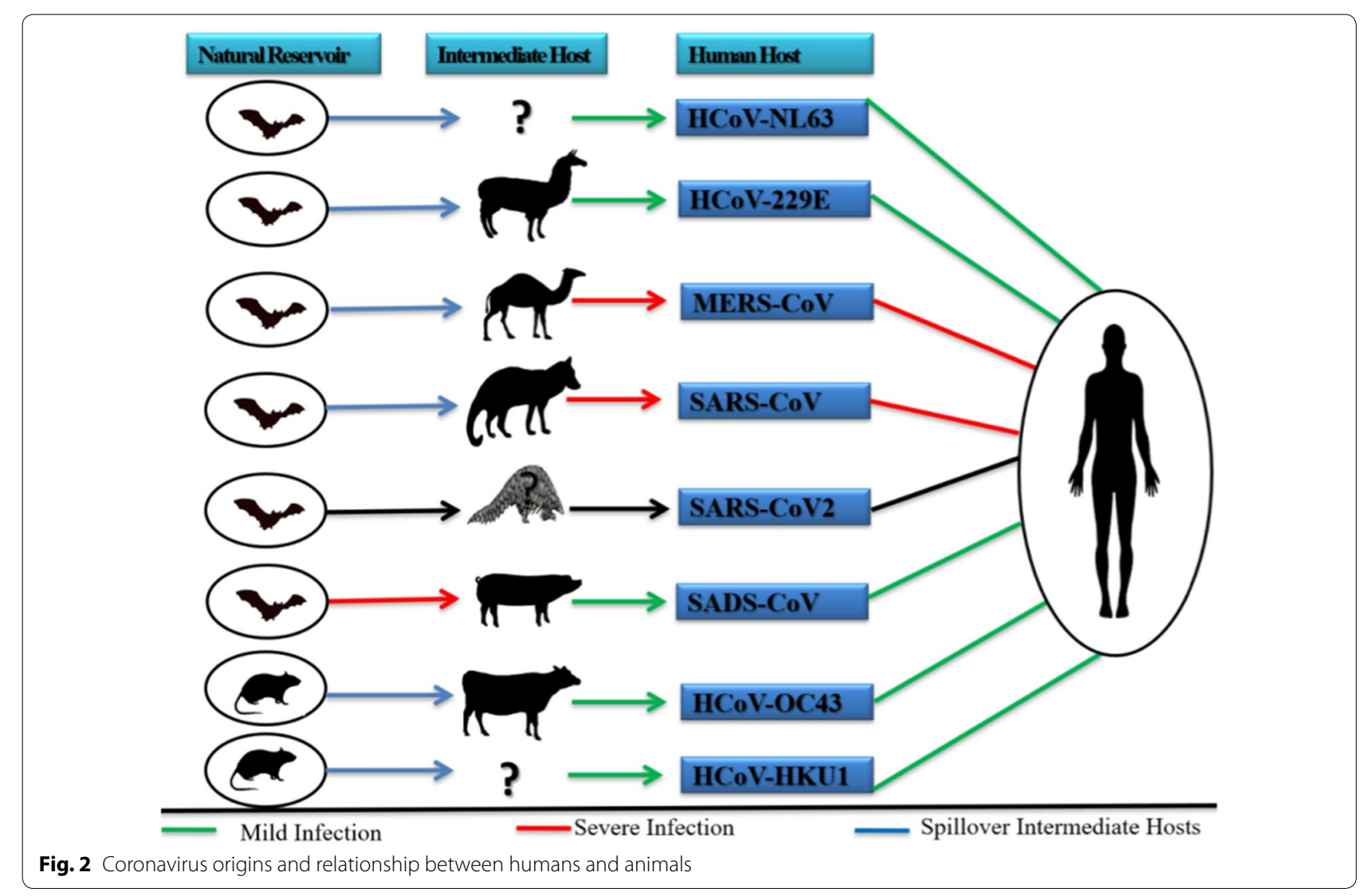


can be assumed that bats are reservoirs for several coronaviruses, including SARS-CoV, MERS-CoV, and SARSCoV-2 [25, 31, 32].

According to reports SARS-CoV-2 is closely related to SARS-CoV [33, 34] and the similarity between the genomes was about $80 \%[3,16,35]$. Though SARS-CoV-2 has most likely originated from bats, it is not yet clear which animal served as an intermediate host and contributed towards the evolution of the virus before the spillover to humans occurred [22].

In another study, it was demonstrated that SARS$\mathrm{CoV}-2$ was a chimeric virus between a bat coronavirus and a coronavirus of unknown origin [36]. In a similar research, it was reported a novel bat-derived coronavirus, denoted RmYN02, identified from the metagenomic analysis of samples from 227 bats collected from Yunnan province in China between May and October 2019 [37]. Notably, RmYN02 shares a 93.3\% nucleotide identity with SARS-CoV-2 at the scale of the complete genome and $97.2 \%$ identity in the ORF1ab gene. It could, therefore, be considered the closest relative of SARS-CoV-2 reported to date. In contrast, RmYN02 showed low sequence identity (61.3\%) with SARS-CoV-2 in the receptor-binding domain (RBD), suggesting that RmYN02 might not bind to angiotensin-converting enzyme 2 (ACE2). Critically, and in a similar manner to SARS-CoV-2, RmYN02 was characterized by the insertion of multiple amino acids at the junction site of the $\mathrm{S} 1$ and $\mathrm{S} 2$ subunits of the spike (S) protein. This provides strong evidence that such insertion events can occur naturally in animal $\beta \mathrm{CoV}[37,39]$.

It can be seen that tiger SARS-CoV-2/USA/ NY-040420 EPI_ISL_420293 shares 99.96\% nucleotide identity with human SARS-CoV-2 reference genome at the complete genome-scale, followed by mink
SARS-CoV-2/NB04 EPI_ISL_447634 (99.90\%), mouse SARS-CoV-2/HRB-26 m EPI_ISL_459910 (99.87\%), cat SARS-CoV-2 EPI_ISL_437349 (99.85\%), and dog SARSCoV-2/HKG/20-03695/2020 (99.51\%) demonstrating a high level of nucleotide identity between SARS-CoV-2 isolates from domestic animals and humans (Table 1).

Also, noteworthy is the shared identity between tiger SARS-CoV-2/USA/NY-040420 EPI_ISL_420293 and mink SARS-CoV-2/NB04 EPI_ISL_447634 (99.89\%), cat SARS-CoV-2 EPI_ISL_437349 and tiger SARSCoV-2 USA NY-040420 EPI_ISL_420293 (99.84\%), cat SARS-CoV-2 EPI_ISL_437349 and mink SARS-CoV-2/ NB04 EPI_ISL_447634 (99.78), cat SARS-CoV- 2 EPI ISL_43734 and dog SARS-CoV-2/HKG/20-03695/2020 (99.39\%), tiger SARS-CoV-2/USA/NY/040420 EPI ISL_420293 and dog SARS-CoV-2/HKG/20-03695/2020 (99, 54\%), and dog SARS-CoV-2/HKG/20-03695/2020 and mink SARS-CoV-2/NB04 EPI_ISL_447634 (99.53\%) (Table 1).

Regarding the percentage of nucleotide identity of the spike protein, dog SARS-CoV-2/HKG/20-03695/2020, tiger SARS-CoV-2 USA NY-040420 EPI_ISL_420293, and cat SARS-CoV-2 EPI_ISL_437349 share 99.97\% with human SARS-CoV-2 (Table 2).The amino acid identity of the spike protein between dog SARSCoV-2/HKG/20-03695/2020, tiger SARS-CoV-2 USA NY-040420 EPI_ISL_42029 and cat SARS-CoV-2 EPI_ ISL_437349 with SARS-CoV-2 is $99.92 \%$ (Table 3 ).

However, the spike protein amino acid and nucleotide identity among tiger SARS-CoV-2/USA/NY/040420 EPI_ISL_42029, dog SARS-CoV-2/HKG/2003695/2020, and cat SARS-CoV-2 EPI_ISL_437349 was 100\% (Tables 2 and 3).

Table 1 Whole-genome nucleotide identity percent among different representative coronaviruses and human SARSCoV-2

\begin{tabular}{|c|c|c|c|c|c|c|c|c|c|c|c|c|c|}
\hline & 1 & 2 & 3 & 4 & 5 & 6 & 7 & 8 & 9 & 10 & 11 & 12 & 13 \\
\hline 1-SARS-CoV-2 Reference genome & 100 & 99.90 & 99.51 & 99.96 & 99.85 & 99.87 & 93.06 & 95.99 & 89.90 & 84.84 & 87.43 & 87.69 & 78.20 \\
\hline 2-Mink SARS-CoV-2/NB04 EPI_ISL_447634 & 99.90 & 100 & 99.53 & 99.89 & 99.78 & 99.86 & 93.06 & 95.99 & 89.89 & 84.50 & 87.37 & 87.63 & 78.21 \\
\hline 3-Dog SARS-CoV-2/HKG/20-03695/2020 & 99.51 & 99.53 & 100 & 99.54 & 99.39 & 99.50 & 93.06 & 95.71 & 89.62 & 84.68 & 87.03 & 87.28 & 78.55 \\
\hline 4-Tiger SARS-CoV-2/USA/NY-040420 EPI_ISL_420293 & 99.96 & 99.89 & 99.54 & 100 & 99.84 & 99.83 & 93.07 & 96.00 & 89.87 & 84.82 & 87.41 & 87.66 & 78.20 \\
\hline 5-Cat SARS-CoV-2 EPI_ISL_437349 & 99.85 & 99.78 & 99.39 & 99.84 & 100 & 99.72 & 92.93 & 95.86 & 89.76 & 84.72 & 87.31 & 87.56 & 78.07 \\
\hline 6-Mouse SARS-CoV-2/HRB-26 m EPI_ISL_459910 & 99.87 & 99.86 & 99.50 & 99.83 & 99.72 & 100 & 93.14 & 96.03 & 89.98 & 84.92 & 87.42 & 87.68 & 78.26 \\
\hline 7-Bat coronavirus RmYNO2 EPI ISL 412977 & 93.06 & 93.06 & 93.06 & 93.07 & 92.93 & 93.14 & 100 & 92.35 & 87.83 & 82.64 & 86.42 & 86.48 & 77.72 \\
\hline 8-Bat coronavirus RaTG13 & 95.99 & 95.99 & 95.71 & 96.00 & 95.86 & 96.03 & 92.35 & 100 & 89.83 & 84.67 & 87.36 & 87.55 & 78.08 \\
\hline 9-Pangolin coronavirus EPI ISL 410721 & 89.90 & 89.89 & 89.62 & 89.87 & 89.76 & 89.98 & 87.83 & 89.83 & 100 & 84.46 & 86.39 & 86.44 & 77.64 \\
\hline 10-Pangolin coronavirus PCoV GX-P5L & 84.84 & 84.50 & 84.68 & 84.82 & 84.72 & 84.92 & 82.64 & 84.67 & 84.46 & 100 & 82.32 & 82.48 & 78.04 \\
\hline 11-Bat SARS-like coronavirus CoVZXC21 & 87.43 & 87.37 & 87.03 & 87.41 & 87.31 & 87.42 & 86.42 & 87.36 & 86.39 & 82.32 & 100 & 97.24 & 79.44 \\
\hline 12-Bat SARS-like coronavirus CoVZC45 & 87.69 & 87.63 & 87.28 & 87.66 & 87.56 & 87.68 & 86.48 & 87.55 & 86.44 & 82.48 & 97.24 & 100 & 79.42 \\
\hline 13-SARS coronavirus civet010 & 78.20 & 78.21 & 78.55 & 78.20 & 78.07 & 78.26 & 77.72 & 78.08 & 77.64 & 78.04 & 79.44 & 79.42 & 100 \\
\hline
\end{tabular}


Table 2 Spike gene nucleotide identity percent among different representative coronaviruses and human SARS-CoV-2

\begin{tabular}{llllllllllllll}
\hline & $\mathbf{1}$ & $\mathbf{2}$ & $\mathbf{3}$ & $\mathbf{4}$ & $\mathbf{5}$ & $\mathbf{6}$ & $\mathbf{7}$ & $\mathbf{8}$ & $\mathbf{9}$ & $\mathbf{1 0}$ & $\mathbf{1 1}$ & $\mathbf{1 2}$ & $\mathbf{1 3}$ \\
\hline 1-SARS-CoV-2 Reference genome & 100 & 99.92 & 99.97 & 99.97 & 99.97 & 99.56 & 72.16 & 92.86 & 83.77 & 83.23 & 74.99 & 75.51 & 72.54 \\
2-Mink SARS-CoV-2/NB04 EPI_ISL_447634 & 99.92 & 100 & 99.95 & 99.95 & 99.95 & 99.48 & 72.09 & 92.78 & 83.74 & 83.18 & 74.91 & 75.43 & 72.49 \\
3-Dog SARS-CoV-2/HKG/20-03695/2020 & 99.97 & 99.95 & 100 & 100 & 100 & 99.53 & 72.14 & 92.83 & 83.74 & 83.20 & 74.96 & 75.48 & 72.52 \\
4-Tiger SARS-CoV-2/USA/NY-040420 EPI_ISL_420293 & 99.97 & 99.95 & 100 & 100 & 100 & 99.53 & 72.14 & 92.83 & 83.74 & 83.20 & 74.96 & 75.48 & 72.52 \\
5-Cat SARS-CoV-2 EPI_ISL_437349 & 99.97 & 99.95 & 100 & 100 & 100 & 99.53 & 72.14 & 92.83 & 83.74 & 83.20 & 74.96 & 75.48 & 72.52 \\
6-Mouse SARS-CoV-2/HRB-26 m EPI_ISL_459910 & 99.56 & 99.48 & 99.53 & 99.53 & 99.53 & 100 & 72.04 & 92.49 & 83.40 & 83.44 & 74.78 & 75.30 & 72.36 \\
7-Bat coronavirus RmYN02 EPI ISL 412977 & 72.16 & 72.09 & 72.14 & 72.14 & 72.14 & 72.04 & 100 & 71.50 & 70.26 & 69.28 & 73.01 & 72.80 & 69.52 \\
8-Bat coronavirus RaTG13 & 92.86 & 92.78 & 92.83 & 92.83 & 92.83 & 92.49 & 71.50 & 100 & 83.25 & 82.76 & 75.85 & 76.01 & 72.53 \\
9-Pangolin coronavirus EPI ISL_410721 & 83.77 & 83.74 & 83.74 & 83.74 & 83.74 & 83.40 & 70.26 & 83.25 & 100 & 79.69 & 79.17 & 79.44 & 72.19 \\
10-Pangolin coronavirus PCoV GX-P5L & 83.23 & 83.18 & 83.20 & 83.20 & 83.20 & 83.44 & 69.28 & 82.76 & 79.69 & 100 & 74.61 & 75.16 & 72.32 \\
11-Bat SARS-like coronavirus CoVZXC21 & 74.99 & 74.91 & 74.96 & 74.96 & 74.96 & 74.78 & 73.01 & 75.85 & 79.17 & 74.61 & 100 & 96.95 & 71.83 \\
12-Bat SARS-like coronavirus CoVZC45 & 75.51 & 75.43 & 75.48 & 75.48 & 75.48 & 75.30 & 72.80 & 76.01 & 79.44 & 75.16 & 96.95 & 100 & 71.67 \\
13-SARS coronavirus civet010 & 72.54 & 72.49 & 72.52 & 72.52 & 72.52 & 72.36 & 69.52 & 72.53 & 72.19 & 72.32 & 71.83 & 71.67 & 100 \\
\hline
\end{tabular}

Table 3 Spike protein amino acid identity percent among different representative coronaviruses and human SARS-CoV-2

\begin{tabular}{|c|c|c|c|c|c|c|c|c|c|c|c|c|c|}
\hline & 1 & 2 & 3 & 4 & 5 & 6 & 7 & 8 & 9 & 10 & 11 & 12 & 13 \\
\hline 1-SARS-CoV-2 Reference genome & 100 & 99.84 & 99.92 & 99.92 & 99.92 & 99.45 & 72.54 & 97.41 & 90.03 & 92.38 & 97.91 & 80.53 & 75.76 \\
\hline 2-Mink SARS-CoV-2/NB04 EPI_ISL_447634 & 99.84 & 100 & 99.92 & 99.92 & 99.92 & 99.29 & 72.38 & 97.25 & 89.87 & 92.22 & 79.75 & 80.38 & 75.61 \\
\hline 3-Dog SARS-CoV-2/HKG/20-03695/2020 & 99.92 & 99.92 & 100 & 100 & 100 & 99.37 & 72.46 & 97.33 & 89.95 & 92.30 & 79.83 & 80.46 & 75.68 \\
\hline 4-Tiger SARS-CoV-2/USA/NY-040420 EPI_ISL_420293 & 99.92 & 99.92 & 100 & 100 & 100 & 99.37 & 72.46 & 97.33 & 89.95 & 92.30 & 79.83 & 80.46 & 75.68 \\
\hline 5-Cat SARS-CoV-2 EPI_ISL_437349 & 99.92 & 99.92 & 100 & 100 & 100 & 99.37 & 72.46 & 97.33 & 89.95 & 92.30 & 79.83 & 80.46 & 75.68 \\
\hline 6-Mouse SARS-CoV-2/HRB-26 m EPI_ISL_459910 & 99.45 & 99.29 & 99.37 & 99.37 & 99.37 & 100 & 72.51 & 96.94 & 89.64 & 92.38 & 79.75 & 80.38 & 75.61 \\
\hline 7-Bat coronavirus RmYN02 EPI ISL 412977 & 72.54 & 72.38 & 72.46 & 72.46 & 72.46 & 72.51 & & & & & 76.66 & & 71.55 \\
\hline 8-Bat coronavirus RaTG13 & 97.41 & 97.25 & 97.33 & 97.33 & 97.33 & 96.94 & 72.76 & 100 & 93.14 & 79.84 & 80.47 & 76.31 & 76.47 \\
\hline 9-Pangolin coronavirus EPI ISL 410721 & 90.03 & 89.87 & 89.95 & 89.95 & 89.95 & 89.64 & 72.76 & 93.14 & 100 & 87.55 & 85.38 & 85.93 & 75.33 \\
\hline 10-Pangolin coronavirus PCoV GX-P5L & 92.38 & 92.22 & 92.30 & 92.30 & 92.30 & 92.38 & 72.96 & 79.84 & 87.55 & 100 & 79.75 & 80.22 & 76.59 \\
\hline 11-Bat SARS-like coronavirus CoVZXC21 & 97.91 & 79.75 & 79.83 & 79.83 & 79.83 & 79.75 & 76.66 & 80.47 & 85.38 & 79.75 & 100 & 98.64 & 75.00 \\
\hline 12-Bat SARS-like coronavirus CoVZC45 & 80.53 & 80.38 & 80.46 & 80.46 & 80.46 & 80.38 & 76.66 & 76.31 & 85.93 & 80.22 & 98.64 & 100 & 75.31 \\
\hline 13-SARS coronavirus civet010 & 75.76 & 75.61 & 75.68 & 75.68 & 75.68 & 75.61 & 71.55 & 76.47 & 75.33 & 76.59 & 75.00 & 75.31 & 100 \\
\hline
\end{tabular}

This result seems to be related to animal species that have been infected by SARS-CoV-2 through humans (dog, cat, and tiger, at first). Transmission to humans does not seem so likely, however, given the identity between nucleotides and amino acids of the spike protein, transmission between animals seem possible. Because it has a similar genome to other animal coronaviruses, SARSCoV-2 may have undergone nucleotide mutation when transmitted to animals, expressing amino acids that increased its pathogenicity in animals, especially those related to spike protein $[38,39]$.

The RBD of SARS-CoV-2 spike protein, which lies in the $\mathrm{S} 1$ domain, is a critical element for determining the susceptibility of the new host species. The studies performed on the interaction between the viral RBD with host cellular receptor (ACE2) revealed snakes, pangolins, and turtles as the potential intermediate hosts [40]. Turtles, along with other animal species, are favored animals in the Huanan Seafood Wholesale Market. However, extended studies are needed to prove their associations scientifically [11].

One of the probable intermediate hosts for SARS$\mathrm{CoV}-2$ is a pangolin. Pangolin-CoV has $91.02 \%$ and 90.55\% identity to SARS-CoV-2 and BatCoV RaTG13, respectively $[33,35]$. Furthermore, the SARS-CoV-2 spike proteins RBD resembles closely Malayan pangolin $\mathrm{CoV}$ (Pangolin-CoV) [40]. These findings suggested that pangolins can be the intermediate host for SARS-CoV-2 transmission. Further research is necessary to confirm the origin and transmission dynamics of SARS-CoV-2.

\section{Positive aspects of coronaviruses transmission from animals to humans}

The possible protective effect of pet-ownership against coronaviruses warrants consideration where coronavirus prevalence is high across the pet population. Canine 
respiratory coronaviruses often occur among dogs. Ownership of an infected pet can lead to the transmission of viruses from animals to humans. Although possible protection caused by the possession of a pet has not yet been found, the frequent occurrence of coronavirus in canines could help the human immune system develop a better response against SARS-CoV-2 [41].

\section{Transmission of SARS-CoV-2 from COVID-19 positive persons to animals}

At the beginning of the SARS-CoV-2 outbreak, it was thought that pets were not susceptible to the SARS$\mathrm{CoV}-2$. However, a natural infection of a cat was reported in Belgium with traces of the virus identified in the collected samples by PCR. This cat exhibited respiratory difficulty, vomiting, and diarrhea, which may indicate active replication of the virus inside the animal [39, 41, 42]. However, the animal was not examined by a veterinarian, so further evaluation such as serology was necessary. In another study, Shi et al. showed that cats could be not only naturally infected with SARS-CoV-2 but also that adolescent cats artificially inoculated with the virus presented severe histological lesions and died [18]. However, in further studies, dogs exhibited seroconversion, but the virus could not be isolated. The susceptibility of cats and ferrets to SARS-CoV-2 could be attributed to the ACE2 (SARS-CoV-2 receptors) [3, 43]. These receptors are expressed in type II pneumocytes serous epithelial cells of tracheobronchial submucosal glands in ferrets [44]. Moreover, the SARS-CoV-2 spike-contacting regions of ACE2 are similar in both ferrets and cats, differing by only two amino acids [5].

The previous reports have shown that SARS-CoV can infect ferrets and cats [26], which implies that ferrets and cats may also be susceptible to SARS-CoV-2. This possibility might be associated with cases of SARS-CoV-2 transmission to animals. In addition to probably sharing the same origin, bats have significant similarities among their genotypes [3, 25, 31, 32, 35, 36].

Based on SARS-CoV epidemiology, the COVID-19 pandemic raises the alarm that animals may become infected and become potential transmitters to humans. The fear of possible transmission of animals to humans and the fact that many residents were forced to leave their animals behind due to evacuation and quarantine, thinking that they would return soon, generated a large number of animal abandonment [45].

Authorities in Hunan and Zhejiang provinces of China also announced that they would start killing pets found in public to prevent the transmission of the virus. This concern intensified in late February 2020, when dogs in Hong Kong tested positive for the new coronavirus, being considered the first known case of transmission of
COVID-19 from humans to animals later, felines [20, 39, $46,47]$.

In a recent study, it was investigated the possible protection conferred by previous exposure of individuals to naturally infected animals with coronaviruses taxonomically related to the circulating SARS-CoV-2 [21, 41, 48-50].

The animals were experimentally infected by SARS$\mathrm{CoV}-2$ via the intranasal route through the receptor ACE2 [51]. Several studies report the use of ACE2 by the new coronavirus as its receptor for cell entry [3, 43]. Dogs were also inoculated, although seroconversion was observed, no virus could be isolated from the inoculated and uninoculated contacts. Further, ferrets showed equal susceptibility to cats, while pigs, chicken, and ducks were found referent to vulnerability [5].

Until now, studies based on RBD domain analysis ruled out the probability of mice, rats, and rabbit's involvement in the SARS-CoV-2 cycle [52]. The findings on ferrets, orangutans, and monkeys showed a higher affinity of ACE2 with the RBD domain of SARS-CoV-2 S protein [53]. A codon-usage based analysis pointed to snakes as a probable host, although these findings were contradicted by subsequent studies [54].

Some researchers revealed that cats could naturally be infected with other coronaviruses such as feline coronavirus (FCoV) just as canines can be infected with canine coronavirus $(\mathrm{CCoV})[55,56]$. These animals probably get infection once the virus binds to the receptor, ACE2 [51].

Another research group conducted a retrospective serological survey on cats infected with SARS-CoV-2 in Wuhan, China. The authors collected 102 samples after the emergence of COVID-19 and included 39 samples collected before the outbreak. Fifteen (14.7\%) of 102 serum samples collected after the outbreak were positive for antibodies against the SARS-CoV-2 receptor-binding domain (RBD) by ELISA test. Among the positive samples, 11 had neutralizing antibodies to SARS-CoV-2 with a titer ranging from $1 / 20$ to $1 / 1080$. Twenty-nine out of the 39 serum samples collected before the outbreak were negative. However, no cat that tested positive on serological tests showed any clinical signs. No serological cross-reactivity was detected between SARS-CoV-2 and type I or II of the feline infectious peritonitis virus (FIPV). As the authors suggested, the cat population studied in Wuhan was infected with SARS-CoV-2 after the beginning of the outbreak [57]. In France, a group of 18 veterinary students investigated the spread of the new coronavirus in 21 pets ( 9 cats and 12 dogs). Eleven cases showed symptoms compatible with COVID-19, while only two confirmed positive for the new coronavirus. Although three of these cats showed clinical signs of respiratory or gastrointestinal disease, no animal was 
considered positive by RT-PCR or by the presence of specific antibodies to SARS-CoV-2 [51].

In a separate study, the researchers demonstrated that ferrets, cats, and dogs could be experimentally infected by SARS-CoV-2 via the intranasal route [40]. Several studies reported that the SARS-CoV-2 uses the same receptor, ACE2, to enter the respiratory mucosa $[3,5$, 43]. This probably indicates the possibility of transmission of SARS-CoV-2 from humans to animals. In a recent experimental study, it was observed that cats infected with SARS-CoV-2 could transmit the virus to naïve cats that come into contact with them [58]. However, whether they can transmit the virus to humans or else, humans can transmit the virus to pets, or other animals are not yet fully understood.

Also, the first non-domesticated animal case of SARSCoV-2 transmission was from a big cat, Nadia, and a 4-year-old Malayan tiger infected from the COVID-19 positive workers at the Bronx Zoo, New York, United States. This was the first known animal infection in the US and a tiger anywhere in the world, and was confirmed by the US Department of Agriculture (USDA), the US Centers for Disease Control and Prevention $(\mathrm{CDC})$, National Veterinary Services Laboratories, and the Wildlife Conservation Society (WCS) [54, 59, 60]. Consequently, COVID-19 was detected in four tigers and three lions. Mild infection of respiratory distress was also noted in two pet cats in the USA [61].

A new case was reported in Moskva, Moskovskaya Oblast, Russia, where a 5-year-old cat tested positive for SARS-CoV-2. Samples (throat and nasal swabs) were taken from the suspect cat to detect SARS-CoV-2. The lab tests were performed using RT-PCR in real-time with electrophoretic detection of amplification products. The obtained amplification reaction product was sequenced using selected specific primers flanking a 232 bp N gene fragment (ORF1ab) of the SARS-CoV-2. The tests showed $100 \%$ identity of the analyzed fragment of the $\mathrm{N}$ gene ORF1ab of the SARS-CoV-2. The animals were quarantined [62].

It was previously shown that SARS-CoV does not infect or cause disease in poultry. Because the COVID-19 virus belongs to the same group as SARS-CoV and uses the same ACE2 host cell receptor, it is highly unlikely that poultry is susceptible to COVID-19. Still, it remains to be scientifically proven [63].

For the phylogenetic analysis, complete genome sequences of the viruses falling in the Betacoronavirus genus were retrieved from NCBI GenBank. The sequences involve SARS-CoV and SARS-CoV-2 of Sarbecovirus subgenus and few of the sequences from different animal species including the dog, mink, rabbit, rat, pangolin, hedgehog, camel, bats, and wild and domestic felines comprising subgenuses Merbecovirus, Embecovirus, Hibecovirus and Nobecovirus within the genus Betacoronavirus (Fig. 3). The sequence alignment was done with ClustalW in MEGA 6.02 software, and phylogeny was constructed using the GTR $+\mathrm{G}+\mathrm{I}$ substitution model applying the maximum likelihood method. In the analysis, canine and feline CoVs of Alphacoronavirus were taken as the outgroup for constructing a phylogenetic tree of Betacoronavirus. All the CoVs of genus Betacoronavirus clustered in their respective subgenus clades. Notably, the mink and tiger virus isolates showed 99.6-99.9\% homology with human SARS-CoV-2 isolates from different parts of the world. Contrarily, the canine Betacoronavirus (CRCoV) from subgenus Embecovirus showed 45.8-46.2\% similarity with SARS-CoV-2. Furthermore, pangolin $\mathrm{CoV}$, SARS-like bat CoVs, and bat CoVs (RaTG13 strain) showed homology between 86.6 and $96.3 \%$ with SARS$\mathrm{CoV}-2$. The camel isolate of MERS-CoV showed a $51 \%$ similarity with SARS-CoV-2 at the nucleotide level (Fig. 3). Our analysis demonstrated a high divergence between animal origin CoVs and SARS-CoV-2 except for a few strains which were isolated from mink and tiger as were the cases of COVID-19 infected persons.

\section{Auspicious mode of transmission of SARS-CoV-2 from humans to animals}

Though the exact ways of transmission of SARSCoV-2 from infected humans to animals are vaguely understood, the possible and promising transmission may occur through touching their noses or mouth by infected hands defiled with respiratory droplets or saliva [64]. At the time of sneezing, coughing, or even talking, infected humans can disseminate respiratory droplets, which have a pivotal role in the transmission of the virus to animals [65]. However, the transmission of the virus from affected people can be facilitated by some favorable risk factors, e.g., kissing, petting, licking, or hugging pet animals [66].

\section{Case of animal-to-human transmission of coronavirus at a mink farm in the Netherlands}

According to the government of the Netherlands, through a letter issued by the Ministry of Agriculture, Nature and Food Quality, it is possible that an employee who worked on a mink farm infected with SARS-CoV-2 contracted the virus, having already been recovered from the disease. Also, research shows that minks can be asymptomatic and that cats play an important role in the potential transfer of viruses between investigated farms [67]. 


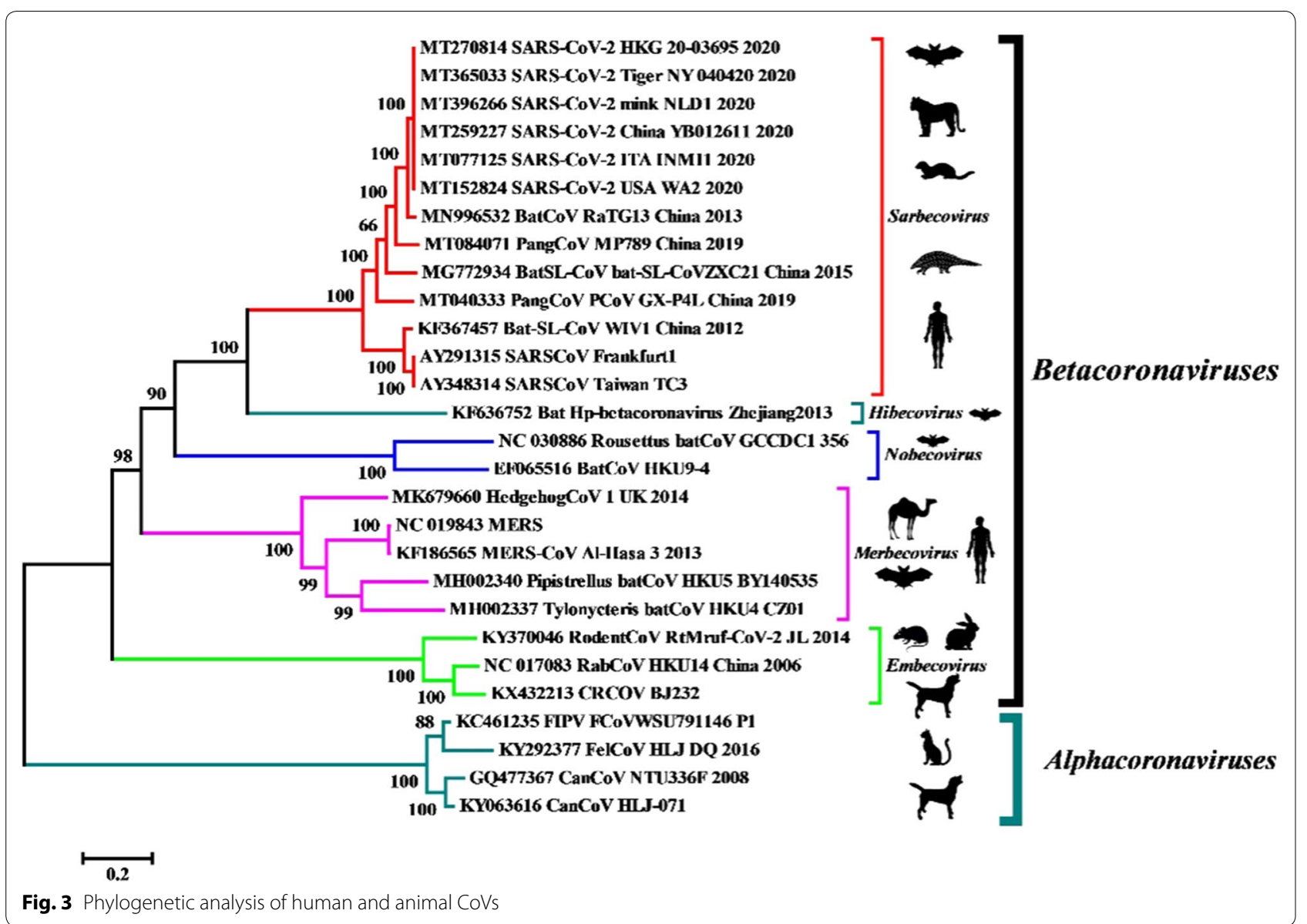

\section{Conclusions}

There are multiple studies on the origin of coronaviruses and their zoonotic potential. Some coronaviruses that infect animals can sometimes be spread to humans and then spread between people as happened in the case of MERS and SARS. This is also what happened with the virus that caused the current outbreak of COVID-19. However, the exact origins of this virus are still unclear. The scientific community has put significant effort into identifying the source of SARS-CoV-2, and to date, genetic evidence suggests that it was likely acquired from bats. The first infections were linked to a live animal market in Wuhan, suggesting a zoonotic origin. The virus is now spreading from person to person and caused one of the most significant pandemics of the recent era. Infection with SARS-CoV-2 has been reported in several animals through serological and molecular analyses and experimental inoculations. However, it is not proved that animals can transmit SARS-CoV-2 to humans and to what extent humans can transmit this virus to animal species. Veterinary public health officials and designated public health officials should work to determine whether animals should be tested for SARS-CoV-2 when the animals are in the same environment as infected owners using a One Health approach. Available information suggests that the risk of SARS-CoV-2 spread from animals to humans is low. Even though human-to-animal transmission or vice versa is possible, caution and effective communication with the pet owners are necessary to prevent the abandonment and death of animals indiscriminately. Although a case of SARS-CoV-2 transmission from animals to humans has already been reported, this is only a report, so further research is needed before declaring that animals can transmit the new coronavirus to humans. Geographic information system (GIS) based on computer and information technology would be useful in analyzing the disease pattern. The collaborative global effort, such as "One-Human-Environmental-Animal Health," is required to reduce the global risk of zoonotic diseases. Further studies are essential to understand better the origin of the virus and transmission dynamics, which will help educate people and avoid unnecessary discrimination to animals. Preventive measures that have proven to be effective should be encouraged, such as correct hygiene, social distance, and, if necessary, social isolation or quarantine. Good practices such as the use of 
footbaths, whirlpools, disinfection of urban areas, and sanitary barriers can be considered.

\begin{abstract}
Abbreviations
COVID-19: Coronavirus disease-2019; SARS-CoV-2: Severe acute respiratory syndrome coronavirus 2; MERS-CoV: Middle East respiratory syndrome coronavirus; aCoV: Alphacoronavirus; $\beta \mathrm{CoV}$ : Betacoronavirus; $\gamma \mathrm{CoV}$ : Gammacoronavirus; $\delta \mathrm{CoV}$ : Deltacoronavirus; CRCoV: Canine respiratory coronavirus; Kb: Kilobase; CFR: Case fatality rate; RBD: Receptor-binding domain; ACE2: Angiotensin-converting enzyme 2; PCR: Polymerase chain reaction; ELISA: Enzyme linked immunosorbent assay; FIPV: Feline infectious peritonitis virus; RT-PCR: Real-time polymerase chain reaction; USDA: US Department of Agriculture; CDC: US Centers for Disease Control and Prevention; WCS: National Veterinary Services Laboratories and the Wildlife Conservation Society; IBV: Infectious bronchitis vírus; NCBI: National Center for Biotechnology Information; GIS: Geographic information system.
\end{abstract}

\section{Acknowledgements}

We would like to thank Dr. Amir Ghorbani of The Ohio State University and João Inácio Magalhães Duarte, for his critical comments on this paper. We gratefully acknowledge the authors, originating, and submitting laboratories of the sequences from the GISAID's EpiCoV ${ }^{\mathrm{TM}}$ Database, on which part of the phylogenetic tree reconstruction is based.

\section{Authors' contributions}

The initial writing was carried out by SST and PMD; the other authors contributed to the complementation, critical review, and final of the manuscript. All authors read and approved the final manuscript.

\section{Funding}

Not applicable.

\section{Availability of data and materials}

All data analyzed or generated during this study are included in this publication and its additional files.

\section{Ethics approval and consent to participate}

Not applicable.

\section{Consent for publication}

Not applicable.

\section{Competing interests}

The authors declare that they have no competing interests.

\section{Author details}

${ }^{1}$ Young Researchers and Elites Club, Science and Research Branch, Islamic Azad University, Tehran, Iran. ${ }^{2}$ Faculty of Biological and Health Sciences, Universidade de Cuiabá (UNIC), Primavera Do Leste, MT, Brazil. ${ }^{3}$ Faculty of Veterinary Medicine, Science and Research Branch, Islamic Azad University, Tehran, Iran. ${ }^{4}$ Kerman University of Medical Sciences, Kerman, Iran. ${ }^{5} \mathrm{~W}$ Harry Feinstone Department of Molecular Microbiology and Immunology, The Johns Hopkins Bloomberg School of Public Health, Baltimore, MD, USA. ${ }^{6}$ Division of Biological Standardization, ICAR-Indian Veterinary Research Institute, Izatnagar, Bareilly, Uttar Pradesh, India. ${ }^{7}$ Research and Development Section, PerNaturam GmbH, 56290 Gödenroth, Germany. ${ }^{8}$ Avian and Rabbit Diseases Department, Faculty of Veterinary Medicine, University of Sadat City, Sadat City, Egypt. ${ }^{9}$ RetroVirox, Inc., San Diego, CA, USA. ${ }^{10}$ Faculty of Health and Social Sciences, University of South-Eastern Norway, Kongsberg, Norway. ${ }^{11}$ Department of Breeding and Genetics, Cholistan University of Veterinary \& Animal Sciences, Bahawalpur, Pakistan. ${ }^{12}$ Department of Microbiology and Hygiene, Faculty of Veterinary Science, Bangladesh Agricultural University, Mymensingh 2202, Bangladesh. ${ }^{13}$ Department of Cardiology, Medical University of Warsaw, Warsaw, Poland. ${ }^{14}$ Grupo de Investigacion Biomedicina, Faculty of Medicine, Fundacion Universitaria Autonoma de las Americas, Pereira, Risaralda, Colombia. ${ }^{15}$ Department of Clinical Science, Faculty of Specialized Veterinary Sciences, Science and Research Branch, Islamic Azad University, Tehran, Iran. ${ }^{16}$ Department of Physiology, Faculty of Specialized Veterinary Sciences, Science and Research Branch, Islamic Azad University, Tehran, Iran.
${ }^{17}$ Emerging and Vector-borne Diseases Program, SACIDS Foundation for One Health, Sokoine University of Agriculture, Morogoro, Tanzania. ${ }^{18}$ Istituto Zooprofilattico Sperimentale dell'Abruzzo e del Molise "G. Caporale", Teramo, Italy. ${ }^{19} \mathrm{Global}$ Health, and Infectious Diseases Research Group, Kumasi Collaborative Center for Research in Tropical Medicine, Kumasi, Ghana. ${ }^{20}$ Department of Zoonoses, Faculty of Veterinary Medicine, Zagazig University, Zagazig, Sharkia Province, Egypt. ${ }^{21}$ Department of Health Sciences, University "Magna Græcia" of Catanzaro, Catanzaro, Italy. ${ }^{22}$ Kanad Hospital, Alain, P.O. Box 1016, Abu Dhabi, UAE. ${ }^{23}$ Department of Comparative Biosciences, Faculty of Veterinary Medicine, University of Tehran, Tehran, Iran. ${ }^{24}$ Department of Clinical Science, Faculty of Veterinary Medicine, Karaj Branch, Islamic Azad University, Karaj, Iran. ${ }^{25}$ Virology Department, Pendik Veterinary Control Institute, Ministry of Food and Forestry, 34890 Pendik-Istanbul, Turkey. ${ }^{26}$ Department of Preparatory (Biology), Al-Ghad International Colleges for Applied Medical Sciences, Riyadh, Saudi Arabia. ${ }^{27}$ Pathobiology Department, Faculty of Veterinary Medicine, Science and Research Branch, Islamic Azad University, Tehran, Iran. ${ }^{28}$ Aeras, Rockville, MD, USA. ${ }^{29}$ Infection Prevention and Control, Technical Unit, Americares, Stamford, UK. ${ }^{30}$ Environmental Virology Laboratory, Water Pollution Research Department, National Research Division, National Research Center, Dokki, Giza 12622, Egypt. ${ }^{31}$ Department of Animal Wealth Development, Faculty of Veterinary Medicine, Suez Canal University, Ismailia 41522, Egypt. ${ }^{32}$ Department of Animal Medicine (Infectious Diseases), Faculty of Veterinary Medicine, Suez Canal University, Ismailia 41522, Egypt. ${ }^{33}$ Department of Virology, Faculty of Veterinary Medicine, Suez Canal University, Ismailia 41522, Egypt.

Received: 3 July 2020 Accepted: 15 September 2020

Published online: 21 September 2020

\section{References}

1. Lu R, Zhao X, Li J, Niu P, Yang B, Wu H, Wang W, Song H, Huang B, Zhu N. Genomic characterisation and epidemiology of 2019 novel coronavirus: implications for virus origins and receptor binding. Lancet. 2020;395(10224):565-74.

2. Wang C, Horby PW, Hayden FG, Gao GF. A novel coronavirus outbreak of global health concern. Lancet. 2020;395(10223):470-3. https://doi. org/10.1016/s0140-6736(20)30185-9.

3. Lai CC, Shih TP, Ko WC, Tang HJ, Hsueh PR. Severe acute respiratory syndrome coronavirus 2 (SARS-CoV-2) and coronavirus disease-2019 (COVID-19): the epidemic and the challenges. Int J Antimicrob Agents. 2020. https://doi.org/10.1016/j.ijantimicag.2020.105924.

4. Munster VJ, Koopmans M, van Doremalen N, van Riel D, de Wit E. A novel coronavirus emerging in China-key questions for impact assessment. N Engl J Med. 2020;382(8):692-4.

5. Shi J, Wen Z, Zhong G, Yang H, Wang C, Huang B, Liu R, He X, Shuai L, Sun Z. Susceptibility of ferrets, cats, dogs, and other domesticated animals to SARS-coronavirus 2. Science. 2020;368(6494):1016-20.

6. Lau SK, Woo PC, Li KS, Tsang AK, Fan RY, Luk HK, Cai J-P, Chan K-H, Zheng B-J, Wang M. Discovery of a novel coronavirus, China Rattus coronavirus HKU24, from Norway rats supports the murine origin of Betacoronavirus 1 and has implications for the ancestor of Betacoronavirus lineage A.J Virol. 2015;89(6):3076-92.

7. Helmy YA, Fawzy M, Elaswad A, Sobieh A, Kenney SP, Shehata AA. The COVID-19 pandemic: a comprehensive review of taxonomy, genetics, epidemiology, diagnosis, treatment, and control. J Clin Med. 2020;9:1225.

8. Woo PC, Lau SK, Chu C-M, Chan K-H, Tsoi H-W, Huang Y, Wong BH, Poon RW, Cai JJ, Luk W-K. Characterization and complete genome sequence of a novel coronavirus, coronavirus HKU1, from patients with pneumonia. J Virol. 2005;79(2):884-95.

9. Woo PC, Lau SK, Lam CS, Lau CC, Tsang AK, Lau JH, Bai R, Teng JL, Tsang CC, Wang M. Discovery of seven novel Mammalian and avian coronaviruses in the genus deltacoronavirus supports bat coronaviruses as the gene source of alphacoronavirus and betacoronavirus and avian coronaviruses as the gene source of gammacoronavirus and deltacoronavirus. J Virol. 2012;86(7):3995-4008.

10. Chen Y, Liu Q, Guo D. Emerging coronaviruses: genome structure, replication, and pathogenesis. J Med Virol. 2020;92(4):418-23.

11. Liu Z, Xiao X, Wei X, Li J, Yang J, Tan H, Zhu J, Zhang Q, Wu J, Liu L. Composition and divergence of coronavirus spike proteins and host ACE2 
receptors predict potential intermediate hosts of SARS-CoV-2. J Med Virol. 2020;92(6):595-601.

12. Su S, Wong G, Shi W, Liu J, Lai ACK, Zhou J, Liu W, Bi Y, Gao GF. Epidemiology, genetic recombination, and pathogenesis of coronaviruses. Trends Microbiol. 2016;24(6):490-502.

13. Pradesh U, Upadhayay PDD, Vigyan PC. Coronavirus infection in equines: a review. Asian J Anim Vet Adv. 2014;9(3):164-76.

14. Mortola E, Roy P. Efficient assembly and release of SARS coronavirus-like particles by a heterologous expression system. FEBS Lett. 2004;576(1-2):174-8.

15. Wang C, Zheng X, Gai W, Zhao Y, Wang H, Wang H, Feng N, Chi H, Qiu B, Li N. MERS-CoV virus-like particles produced in insect cells induce specific humoural and cellular immunity in rhesus macaques. Oncotarget. 2017;8(8):12686.

16. Malik YS, Sircar S, Bhat S, Sharun K, Dhama K, Dadar M, Tiwari R, Chaicumpa W. Emerging novel coronavirus (2019-nCoV)—current scenario, evolutionary perspective based on genome analysis and recent developments. Vet Q. 2020;40(1):68-76.

17. Rehman SU, Shafique L, Ihsan A, Liu Q. Evolutionary trajectory for the emergence of novel coronavirus SARS-CoV-2. Pathogens. 2020;9(3):240. https://doi.org/10.3390/pathogens9030240.

18. Kelley LA, Mezulis S, Yates CM, Wass MN, Sternberg MJ. The Phyre2 web portal for protein modeling, prediction and analysis. Nat Protoc. 2015;10:845. https://doi.org/10.1038/nprot.2015.053.

19. Andersen KG, Rambaut A, Lipkin WI, Holmes EC, Garry RF. The proximal origin of SARS-CoV-2. Nat Med. 2020;26(4):450-2.

20. Agriculture, Fisheries and Conservation Department (AFCD). Low-level of infection whit COVID-19 in pet dog. In: Agriculture, Fisheries and Conservation Department (AFCD) (ed). https://www.afcd.gov.hk/english/publi cations/publications_press/pr2342.html. Accessed 3 Apr 2020.

21. Tilocca B, Soggiu A, Musella V, Britti D, Sanquinetti M, Urbani A, Roncada P. Molecular basis of COVID-19 relationships in different species: a one health perspective. Microbes Infect. 2020;22:218-20.

22. Junejo Y, Ozaslan M, Safdar M, et al. Novel SARS-CoV-2/COVID-19: origin, pathogenesis, genes and genetic variations, immune responses and phylogenetic analysis. Gene Rep. 2020;20:100752.

23. World Health Organization WHO: summary table of SARS cases by country, 1 November 2002-7 August 2003. Wkly Epidemiol Rec Relevé épidémiologique hebdomadaire. 2003;78(35):305-312. https://apps.who. int/iris/handle/10665/232252. Accessed 3 Apr 2020.

24. Lau SK, Woo PC, Li KS, Huang Y, Tsoi H-W, Wong BH, Wong SS, Leung S-Y, Chan K-H, Yuen K-Y. Severe acute respiratory syndrome coronavirus-like virus in Chinese horseshoe bats. Proc Natl Acad Sci. 2005;102(39):14040-5

25. Li W, Shi Z, Yu M, Ren W, Smith C, Epstein JH, Wang H, Crameri G, Hu Z, Zhang $\mathrm{H}$. Bats are natural reservoirs of SARS-like coronaviruses. Science. 2005;310(5748):676-9.

26. Martina BE, Haagmans BL, Kuiken T, Fouchier RA, Rimmelzwaan GF, Van Amerongen G, Peiris JM, Lim W, Osterhaus AD. SARS virus infection of cats and ferrets. Nature. 2003;425(6961):915.

27. Zaki AM, Van Boheemen S, Bestebroer TM, Osterhaus AD, Fouchier RA Isolation of a novel coronavirus from a man with pneumonia in Saudi Arabia. N Engl J Med. 2012;367(19):1814-20.

28. van Boheemen S, de Graaf M, Lauber C, Bestebroer TM, Raj VS, Zaki AM, Osterhaus AD, Haagmans BL, Gorbalenya AE, Snijder EJ. Genomic characterization of a newly discovered coronavirus associated with acute respiratory distress syndrome in humans. MBio. 2012;3(6):e00473-00412.

29. Reusken CB, Haagmans BL, Müller MA, Gutierrez C, Godeke G-J, Meyer B, Muth D, Raj VS, Smits-De Vries L, Corman VM. Middle East respiratory syndrome coronavirus neutralising serum antibodies in dromedary camels: a comparative serological study. Lancet Infect Dis. 2013;13(10):859-66.

30. Corman VM, Jores J, Meyer B, Younan M, Liljander A, Said MY, Gluecks I, Lattwein E, Bosch B-J, Drexler JF. Antibodies against MERS coronavirus in dromedary camels, Kenya, 1992-2013. Emerg Infect Dis. 2014;20(8):1319.

31. Annan A, Baldwin H, Corman V, Klose S, Owusu M, Nkrumah E, Badu E, Anti P, Agbenyega O, et al. Human betacoronavirus 2c EMC/2012-related viruses in bats, Ghana and Europe. Emerg Infect Dis. 2013;19:456-9.

32. Hampton T. Bats may be SARS reservoir. JAMA. 2005;294(18):2291.

33. Kim Y-I, Kim S-G, Kim S-M, Kim E-H, Park S-J, Yu K-M, Chang J-H, Kim EJ, Lee S, Casel MAB. Infection and rapid transmission of SARS-CoV-2 in ferrets. Cell Host Microbe. 2020;27:704-9.
34. Petrosillo N, Viceconte G, Ergonul O, Ippolito G, Petersen E. COVID-19, SARS and MERS: are they closely related? Clin Microbiol Infect. 2020. https://doi.org/10.1016/j.cmi.2020.03.026.

35. Zhang T, Wu Q, Zhang Z. Probable pangolin origin of SARS-CoV-2 associated with the COVID-19 outbreak. Curr Biol. 2020;30:1346-51.

36. Ji W, Wang W, Zhao X, Zai J, Li X. Homologous recombination within the spike glycoprotein of the newly identified coronavirus may boost cross-species transmission from snake to human. J Med Virol. 2020.

37. Zhou H, Chen X, Hu T, Li J, Song H, Liu Y, Wang P, Liu D, Yang J, Holmes EC. A novel bat coronavirus closely related to SARS-CoV-2 contains natural insertions at the S1/S2 cleavage site of the spike protein. Curr Biol. 2020;30:2196-203.

38. Wan Y, Shang J, Graham R, Baric RS, Li F. Receptor recognition by the novel coronavirus from Wuhan: an analysis based on decade-long structural studies of SARS coronavirus. J Virol. 2020;94:e00127-20.

39. Khailany RA, Safdar M, Ozaslan M. Genomic characterization of a novel SARS-CoV-2. Gene Rep. 2020;19:100682.

40. Liu Y, Chen H, Tang K, Guo Y. Clinical manifestations and outcome of SARS-CoV-2 infection during pregnancy. J Infect. 2020. https://doi. org/10.1016/j.jinf.2020.02.028.

41. Jurgiel J, Filipiak KJ, Szarpak Ł, Jaguszewski M, Smerka J, Dzieciątkowski T. Do pets protect their owners in the COVID-19 era? Med Hypotheses. 2020;142:109831.

42. Chini M. Coronavirus: Belgian cat infected by owner. The Brussels Times. 2020. https://www.brusselstimes.com/all-news/belgium-allnews/103003/coronavirus-belgian-woman-infected-her-cat/. Accessed 3 Apr 2020.

43. Hoffmann M, Kleine-Weber H, Schroeder S, Krüger N, Herrler T, Erichsen S, Schiergens TS, Herrler G, Wu N-H, Nitsche A. SARS-CoV-2 cell entry depends on ACE2 and TMPRSS2 and is blocked by a clinically proven protease inhibitor. Cell. 2020;181:271-80.

44. Van den Brand J, Haagmans BL, Leijten L, van Riel D, Martina BE, Osterhaus A, Kuiken T. Pathology of experimental SARS coronavirus infection in cats and ferrets. Vet Pathol. 2008;45(4):551-62.

45. Kim A. Cats and dogs abandoned at the start of the coronavirus outbreak are now starving or being killed. CNN. 2020. https://edition.cnn. com/2020/03/15/asia/coronavirus-animals-pets-trnd/index.html. Accessed 3 Apr 2020

46. Mallapaty S. Coronavirus can infect cats-dogs, not so much. Nature. 2020. https://doi.org/10.1038/d41586-020-00984-8.

47. World Organization for Animal Health OIE. Immediate notification. https://www.oie.int/wahis_2/public/wahid.php/Reviewreport/Revie w? page_refer=MapFullEventReport\&reportid=33832. Accessed 3 Apr 2020.

48. Decaro N, Lorusso A. Novel human coronavirus (SARS-CoV-2): a lesson from animal coronaviruses. Vet Microbiol. 2020;244(2020):108693. https:// doi.org/10.1056/NEJM199908193410802.

49. Tilocca B, Soggiu A, Sanguinetti M, Babini G, De Maio F, Britti D, Zecconi A, Bonizzi L, Urbani A, Roncada P. Immunoinformatic analysis of the SARS$\mathrm{CoV}-2$ envelope protein as a strategy to assess cross-protection against COVID-19. Microbes Infect. 2020;22:182-7.

50. Tilocca B, Soggiu A, Sanguinetti M, Musella V, Britti D, Bonizzi L, Urbani A, Roncada P. Comparative computational analysis of SARS-CoV-2 nucleocapsid protein epitopes in taxonomically related coronaviruses. Microbes Infect. 2020;22:188-94.

51. Sun SH, Chen Q, Gu HJ, Yang G, Wang YX, Huang XY, Liu SS, Zhang NN, Li XF, Xiong R, Guo Y, Deng YQ, Huang WJ, Liu Q, Liu QM, Shen YL, Zhou Y, Yang X, Zhao TY, Fan CF, Zhou YS, Qin CF, Wang YC. A mouse model of SARS-CoV-2 infection and pathogenesis. Cell Host Microbe. 2020. https:// doi.org/10.1016/j.chom.2020.05.020.

52. Lutz C, Maher L, Lee C, Kang W. COVID-19 preclinical models: human angiotensin-converting enzyme 2 transgenic mice. Hum Genom. 2020;14:20. https://doi.org/10.1186/s40246-020-00272-6.

53. Wan Y, Shang J, Graham R, Baric RS, Li F. Receptor recognition by novel coronavirus from Wuhan: an analysis based on decade-long structural studies of SARS. J Virol. 2020. https://doi.org/10.1128/JVI.00127-20.

54. Ji W, Wang W, Zhao X, Zai J, Li X. Cross-species transmission of the newly identified coronavirus 2019-nCoV. J Med Virol. 2020;92(4):433-40.

55. Buonavoglia C, Decaro N, Martella V, Elia G, Campolo M, Desario C, Castagnaro M, Tempesta M. Canine coronavirus highly pathogenic for dogs. Emerg Infect Dis. 2006;12(3):492. 
56. Jaimes JA, Millet JK, Stout AE, André NM, Whittaker GR. A tale of two viruses: the distinct spike glycoproteins of feline coronaviruses. Viruses. 2020;12(1):83

57. Zhang Q, Zhang H, Huang K, Yang Y, Hui X, Gao J, et al. SARS-CoV-2 neutralizing serum antibodies in cats: a serological investigation, bioRxiv. 2020. https://doi.org/10.1101/2020.04.01.021196.

58. Halfmann PJ, Hatta M, Chiba S, Maemura T, Fan S, Takeda M, Kinoshita N, Hattori S-I, Sakai-Tagawa Y, Iwatsuki-Horimoto K. Transmission of SARSCoV-2 in domestic cats. N Engl J Med. 2020;383:592-4.

59. Law T, Leung H. A tiger at the Bronx Zoo has tested positive for coronavirus. TIME. 2020. https://time.com/5815939/tiger-bronx-zoo-posit ive-coronavirus/. Accessed 3 Apr 2020

60. Centers for Disease Control and Prevention CDC. Coronavirus disease 2019 (COVID-19). If you have animals. https://www.cdc.gov/coronaviru s/2019-ncov/daily-life-coping/pets.html. Accessed 3 Apr 2020.

61. Centers for Disease Control and Prevention CDC. Confirmation of COVID-19 in two pet cats in New York. https://www.cdc.gov/media/relea ses/2020/s0422-covid-19-cats-NYC.html. Accessed 3 Apr 2020.

62. World Organization for Animal Health OIE. Immediate notification. https ://www.oie.int/wahis_2/public/wahid.php/Reviewreport/Review?page refer $=$ MapFullEventReport\&reportid=34443\&newlang=en. Accessed 3 Apr 2020.

63. Jackwood MW. What we know about avian coronavirus infectious bronchitis virus (IBV) in poultry and how that knowledge relates to the virus causing COVID-19 in humans. Associação Portuguesa de Ciência Avícola APCA. 2020. http://www.apcapt.com/what-we-know-about-avian-coron avirus-infectious-bronchitis-virus-ibv-in-poultry-and-how-that-knowl edge-relates-to-the-virus-causing-covid-19-in-humans/. Accessed $3 \mathrm{Apr}$ 2020.

64. Chen J. Pathogenicity and transmissibility of 2019-nCoV—a quick overview and comparison with other emerging viruses. Microbes Infect. 2020;22:69-71

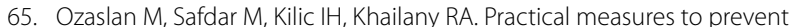
COVID-19: a mini-review. J Biol Sci. 2020;20:100-2.

66. Leroy EM, Gouilh MA, Brugère-Picoux J. The risk of SARS-CoV-2 transmission to pets and other wild and domestic animals strongly mandates a one-health strategy to control the COVID-19 pandemic. One Health. 2020. https://doi.org/10.1016/j.onehlt.2020.100133.

67. Stand van zaken onderzoek COVID-19 naar nertsenbedrijven. (Ministerie van Landbouw, Natuur em Voedselkwaliteit eds.). https://www.rijksoverh eid.nl/documenten/brieven/2020/05/19/stand-van-zaken-onderzoekcovid-19-naar-nertsenbedrijven. Accessed 14 Aug 2020.

\section{Publisher's Note}

Springer Nature remains neutral with regard to jurisdictional claims in published maps and institutional affiliations.
Ready to submit your research? Choose BMC and benefit from:

- fast, convenient online submission

- thorough peer review by experienced researchers in your field

- rapid publication on acceptance

- support for research data, including large and complex data types

- gold Open Access which fosters wider collaboration and increased citations

- maximum visibility for your research: over $100 \mathrm{M}$ website views per year

At $\mathrm{BMC}$, research is always in progress.

Learn more biomedcentral.com/submissions 